\title{
Važnost aktivne politike zapošljavanja i njezine evaluacije u Hrvatskoj
}

\author{
UDK: 331.5.024.5(497.5) \\ doi: 10.3935/rsp.v27i3.1762
}

Zaposlenost ima temeljnu ulogu u svakom društvu. Ljude često definiramo, a i oni sebe određuju, ovisno o tome što rade u životu. U sociološkim i ekonomskim studijama ističe se da zaposlenost nije samo najvažnija odrednica položaja ljudi u svakoj zemlji, već je ujedno bitna za stvaranje smisla, dohotka, socijalne stabilnosti i kvalitete života te sudjelovanja u društvu (Diamond i Lodge, 2013.; Farnsworth i Irving, 2010.). Zaposlenost se naziva $»$ jepilom koje drži naše društvo na okupu«. Rad se smatra najboljim oblikom socijalne skrbi, a razlozi su jasni: ekonomska neovisnost i socijalna uključenost. Tako je povećanje stope zaposlenosti postalo ključni cilj socijalne politike i politike tržišta rada razvijenih industrijskih zemalja (Grosh, del Ninno, Tesliuc, Ouerghi, 2008.; Starke, Kaasch, van Hooren, 2011.).

Postoji opća suglasnost da je nezaposlenost jedan od najtežih ekonomskih i društvenih problema za zajednicu i njome pogođene pojedince. Nezaposlenost predstavlja propuštanje proizvodnje i prihoda, izaziva visoke fiskalne troškove, pridonosi značajnoj razgradnji ljudskog kapitala, povećava neravnopravnost (nejednakost) u društvu jer u kriznim uvjetima nezaposleni više gube od zaposlenih. Kod pogođenih, nezaposlenost izaziva značajna psihološka opterećenja ostavljajući dojam beskorisnosti i bezizglednosti te, konačno, stvara socijalnu isključenost. Ako su ljudi zaposleni, mnogo je manja vjerojatnost da će biti siromašni nego ako su nezaposleni. Nastoji se stoga osigurati bolji položaj ljudi radom i ostvarivanjem prava na plaću umjesto da u sustavu nezaposlenosti i skrbi primaju pomoć te naknadu. Nažalost, u Hrvatskoj, kao i u mnogim tranzicijskim zemljama, brojni su ljudi nezaposleni i/ili slabo zapošljivi, zbog čega su izloženi ekonomskom siromaštvu i socijalnoj isključenosti.

Nije potrebno podsjećati kako u većini slučajeva tržište rada nije savršeno te istodobno postoje nezaposlenost i nepopunjena potražnja za radnicima. To znači da, pogotovo u zemljama poput Hrvatske s visokom nezaposlenošću, postoji prostor za poboljšanje djelovanja tržišta rada, približavajući nezaposlenost minimumu potražnje i ponude za radom te smanjujući otvorenu nezaposlenost i broj nepopunjenih radnih mjesta. Aktivna politika zapošljavanja (APZ) može pomoći u ublažavanju (smanjivanju) strukturnog (frikcijskog) nesklada između ponude i potražnje u prvom redu smanjivanjem profesionalnog i prostornog nesklada između ponude i potražnje te povećanjem transparentnosti tržišta rada. Najvažniji instrumenti APZ-a za poboljšanje usklađenosti su osposobljavanje i usavršavanje, informiranje i savjetovanje s obzirom na potražnju posla i odabira kod zapošljavanja s jedne strane te posredovanja kod zapošljavanja s druge. Matković (2008.) naglašava kako su aktivne politike zapošljavanja u prvom redu namijenjene aktivaciji i zapošljavanju onih nezaposlenih (odnosno skupina nezaposlenih) koji imaju najviše poteškoća sa zapošljavanjem. Aktivna politika nije (ili ne bi trebala biti) skup univerzalnih mjera zapošljavanja namijenjenih svima. Te mjere imaju za cilj poboljšati pristup zaposlenosti pojedinim ranjivim skupinama, odnosno 
omogućiti im očuvanje veze s tržištem rada, olakšati im nalaženje posla i povećati vjerojatnost njihovog zadržavanja u svijetu rada.

APZ može preraspodijeliti mogućnosti zapošljavanja tako da manje ljudi postane dugotrajno nezaposleno i/ili korisnici-primatelji pomoći u sustavu socijalne skrbi. Kada su zadane ukupna zaposlenost i ukupna ponuda rada, to bi značilo rasporediti teret nezaposlenosti na više ljudi (pretpostavljajući da kao rezultat političke intervencije nezaposlenošću nisu pogođeni isti ljudi u različitim vremenskim intervalima). Mnogo povoljniji učinak APZ-a bio bi povećanje ukupne zaposlenosti od preraspodjele nezaposlenosti na veći broj ljudi. Ekonomska teorija navodi kako APZ ima vrlo slab i/ili gotovo nema neposrednog utjecaja na ukupnu zaposlenost, ali ako uspije u radnom uključivanju dugotrajno nezaposlenih ili korisnika-primatelja pomoći u sustavu socijalne skrbi, povećava se djelotvornost ponude rada. Stoga je uključivanje dugotrajno nezaposlenih ili sprječavanje dugotrajne nezaposlenosti sigurno vrijedno pozornosti. Pored plaćene zaposlenosti, ujedno postoje druge korisne aktivnosti koje mogu biti način socijalnog uključivanja (integracije) te osobnog ispunjavanja i potvrđivanja. Bez daljnjeg bi sprječavanje dugotrajne i ponovljene nezaposlenosti bilo najvažniji doprinos sprječavanju siromaštva i socijalne isključenosti pogotovo korisnika pomoći u sustavu socijalne skrbi. Nakon ovih uvodnih napomena, u idućoj dionici teksta izlažu se različiti tipovi aktivne politike zapošljavanja. Slijedi osvrt na evaluaciju mjera aktivne politike zapošljavanja u Hrvatskoj.

\section{RAZLIČITI PROGRAMI AKTIVNE POLITIKE ZAPOŠLJAVANJA}

Aktivne politike zapošljavanja imaju različite ciljeve ovisno o načinu pristupanja ekonomskim i socijalnim problemima kao i različite metode i alate provedbe. Bonoli (2010.) razlikuje četiri idealna tipa aktivne politike zapošljavanja, što je prikazano u Tablici 1 .

Tablica 1.

Četiri idealna tipa aktivnih politika zapošljavanja

\begin{tabular}{|c|c|c|}
\hline Tip & Cilj & Načini i alati \\
\hline $\begin{array}{l}\text { Pojačanje } \\
\text { poticaja }\end{array}$ & $\begin{array}{l}\text { - ojačati pozitivne i negativne radne poticaje za } \\
\text { osobe koje primaju naknadu }\end{array}$ & $\begin{array}{l}\text { - porezne olakšice, naknade za zaposlene } \\
\text { - vremenska ograničenja trajanja naknada } \\
\text { - smanjenje naknada } \\
\text { - uvjetovanost naknada } \\
\text { - sankcije }\end{array}$ \\
\hline $\begin{array}{l}\text { Pomoć u } \\
\text { zapošlja- } \\
\text { vanju }\end{array}$ & $\begin{array}{l}\text { - ukloniti prepreke za zapošljavanje i olakšati } \\
\text { (ponovni) ulazak na tržište radne snage }\end{array}$ & $\begin{array}{l}\text { - službe zapošljavanja } \\
\text { - subvencije za zapošljavanje } \\
\text { - savjetovanja } \\
\text { - programi traženja posla }\end{array}$ \\
\hline $\begin{array}{l}\text { Javni } \\
\text { radovi i } \\
\text { workfare }\end{array}$ & $\begin{array}{l}\text { - obvezno sudjelovanje nezaposlenih osoba u pro- } \\
\text { gramima javnih radova i ostvarivanju društveno } \\
\text { korisnog rada, ograničavanje propadanje ljud- } \\
\text { skog kapitala tijekom razdoblja nezaposlenosti } \\
\text { - sustav otvaranja radnih mjesta u javnom sektoru } \\
\text { - programi usavršavanja i osposobljavanja koji } \\
\text { nisu vezani za zaposlenje } \\
\text { - investiranje u ljudski kapital } \\
\text { - pojačati zapošljivost }\end{array}$ & $\begin{array}{l}\text { - model otvaranja radnih mjesta u javnom } \\
\text { sektoru } \\
\text { - programi usavršavanja i osposobljavanja } \\
\text { koji nisu vezani uz zapošljavanje }\end{array}$ \\
\hline $\begin{array}{l}\text { Ulaganje } \\
\text { u ljudski } \\
\text { kapital }\end{array}$ & $\begin{array}{l}\text { - pojačati izglede za pronalaženje zaposlenja } \\
\text { putem poboljšanja vještina, stručnosti i spo- } \\
\text { sobnosti nezaposlenih }\end{array}$ & $\begin{array}{l}\text { - osnovno obrazovanje } \\
\text { - stručno usavršavanje i osposobljavanje }\end{array}$ \\
\hline
\end{tabular}

Izvor: Bonoli, (2010.). 
Prvi tip aktivne politike zapošljavanja, pojačanje poticaja, obuhvaća mjere usmjerene na osnaživanje pozitivnih i negativnih radnih poticaja za primatelje novčanih naknada, u smislu smanjenja iznosa i trajanja naknada te uvjetovanja njihovog sudjelovanja u radnim aktivnostima $\mathrm{i} / \mathrm{ili}$ drugim programima tržišta rada. Drugi tip APZ-a usmjeren je na uklanjanje prepreka za ulazak, povratak i zadržavanje na tržištu rada, gdje spadaju službe za zapošljavanje, programi promjene posla, savjetovanje itd. (što se ponajviše preventivno provodi u skandinavskim zemljama). Treći tip mjera usmjeren je na obvezno sudjelovanje nezaposlenih osoba u programima javnih radova i ostvarivanju društveno korisnog rada čime se sprječava ili barem ublažava propadanje ljudskog kapitala tijekom razdoblja nezaposlenosti. Četvrti tip APZ-a osigurava stručno osposobljavanje i usavršavanje nezaposlenih osoba i/ili ponovno stjecanje znanja, stručnosti i vještina za one osobe čije su vještine zastarjele ili zaboravljene.

Naravno, različiti programi trebali bi imati raznovrsne učinke. U slučaju programa obrazovanja i osposobljavanja, to bi se trebalo ostvariti zahvaljujući povećanoj zapošljivosti uslijed stečenih novih znanja, vještina i sposobnosti. U slučaju subvencioniranog (sufinanciranog) zapošljavanja poslodavcima su takve osobe financijski privlačnije naspram ostalih nezaposlenih koji nisu subvencionirani. U slučaju javnih radova pozitivan učinak može se ostvariti zahvaljujući aktivnom angažmanu u zajednici i svijetu rada. Ovi programi sudionicima nakon dugog razdoblja neaktivnosti omogućuju stjecanje iskustva, znanja i stvaranje društvene mreže koja je nužna pri uspješnom nalaženju posla.

Nešto drugačiju klasifikaciju mjera APZ-a u Labour Market Policy Methodology 2013 navodi EUROSTAT (2013.) koji vodi baze podataka o aktivnoj politici zapošljavanja. Tu su sadržane sve javne in- tervencije opće države na tržište rada provedene s ciljem poboljšanja njegovog učinkovitog funkcioniranja i ispravljanja tržišnih neravnoteža. Javne intervencije odnose se na radnje koje poduzima država u pogledu financiranja mjera, ali i obliku javnih fiskalnih izdataka (što su smanjeni javni prihodi zbog oprosta ili umanjenja poreza, doprinosa za socijalno osiguranje ili plaćanja neke druge obveze). Opća država ovdje uključuje središnju državu, regionalne vlasti, lokalnu upravu i javne fondove. U mnogim slučajevima izravni primatelj javnih rashoda može biti poslodavac ili davatelj usluga, ali krajnji korisnik provedenih mjera je sudionik - član neke ciljne skupine APZ-a. Postoje tri različite vrste intervencije:

- Usluge - odnose se na intervencije na tržištu rada u kojima je glavna aktivnost sudionika traženje posla i obično ne dolazi do promjena njihovog statusa na tržištu rada, odnosno ostaju nezaposleni. Usluge također obuhvaćaju i djelovanje javnih službi za zapošljavanje koje nisu izravno povezane sa sudionicima. To uključuje posredovanje i druge usluge za poslodavce, administrativne i druge poslove koje obično rade javne službe za zapošljavanje.

- Mjere - odnose se na intervencije na tržištu rada u kojima je aktivnost sudionika na traženju posla povezana sa sudjelovanjem u programima uslijed kojih dolazi do promjene njihovog statusa na tržištu rada. Kao mjere mogu se smatrati i aktivnosti u kojima ne dolazi do promjene statusa na tržištu rada, ako ispunjavaju sljedeće kriterije: 1) poduzete aktivnosti nisu vezane s traženjem posla, nego se ostvaruju pod nadzorom i zahtijevaju puno radno vrijeme ili veći dio radnog vremena sudionika u značajnom vremenskom razdoblju, 2) cilj je poboljšati strukovne kvalifikacije sudionika ili 3) intervencije potiču zapošljavanje (uključujući i samo- 
zapošljavanje). Baza mjera APZ-a pokriva, prije svega, državne intervencije koje pružaju privremenu podršku skupinama u nepovoljnom položaju na tržištu rada. Većina mjera usmjerena je na aktiviranje nezaposlenih, odnosno pomaganje osobama na izlasku iz prisilne neaktivnosti u zaposlenost i/ili održavanje radnih mjesta za osobe kojima prijeti nezaposlenost. Jedine mjere u bazi podataka koje ne pružaju privremenu podršku odnose se na stalnu podršku osobama s trajno smanjenim radnim sposobnostima. U tom slučaju priznaje se kako javna podrška može biti potrebna da se ublaže posljedice smanjene radne sposobnosti. Ovaj tip intervencija predstavlja aktivne politike zapošljavanja u užem smislu te će shodno tome biti predmet analize $u$ nastavku.

- Potpore-odnose se na intervencije koje pružaju izravnu ili neizravnu financijsku pomoć osobama vezane uz sudjelovanje na tržištu rada ili koje kompenziraju pojedince zbog njihovog nezavidnog položaja na tržištu rada. Sudionici su obično osobe koje su bez posla i aktivno traže posao.

Prema navedenoj publikaciji EUROSTAT-a (Table A, str. 13) aktivne politike zapošljavanja podrazumijevaju pet skupina mjera, koje se pobliže obrazlažu. To su:

- obrazovanje i osposobljavanje (eng. training) - omogućavaju usklađivanje ponude i potražnje za radom u uvjetima strukturnih neusklađenosti. Radi se o tome da postoje radna mjesta koja se ne uspijevaju popuniti, odnosno kada upravo nedostatak odgovarajućih radnika ograničava otvaranje novih radnih mjesta usprkos potražnji na tržištu proizvoda i raspoloživom kapitalu za pokretanje proizvodnje. Dodani je učinak moguć na unaprjeđenju radnih sposobnosti ugroženih skupina među nezaposlenima kako bi im se poboljšala zapošljivost i izjednačile mogućnosti zapošljavanja s drugim osobama.

- poticaji za zapošljavanje (eng. employment incentives) - postoji opasnost ako se radi o radnom mjestu na kojem proizvodnost odgovara plaćanju iznosa pune nadnice, takvi subvencionirani poslovi zbog manjih troškova mogu istisnuti istovrsne poslove u konkurentskim poduzećima. Subvencionirano zapošljavanje može biti i oblik izjednačavanja mogućnosti zapošljavanja ugroženih skupina na način da postanu privlačniji poslodavcima iako su u nepovoljnijem položaju na tržištu rada. Tu se mogu svrstati i raznovrsni oblici subvencioniranja pripravništva i stručne prakse kojima se olakšava prijelaz iz obrazovanja u svijet rada.

- zaštitne radionice i rehabilitacija (eng. sheltered and supported employment and rehabilitation) - pomažu u punopravnom uključivanju i sudjelovanju osoba s invaliditetom u društvu. Takva osoba zaposlenjem stječe materijalnu sigurnost, veću samostalnost u odlučivanju o životnim pitanjima, članovi zajednice drugačije je percipiraju, a uz odgovarajući sustav profesionalne (radne) rehabilitacije mnoge osobe s invaliditetom mogu biti u potpunosti ravnopravni članovi društva i pridonositi vlastitoj i općoj dobrobiti, umjesto da su samo primatelji pomoći i korisnici raznovrsnih beneficija. Stoga je usvojena Europska strategija za osobe $s$ invaliditetom 2010.-2020., kao i drugi relevantni dokumenti vezani uz antidiskriminacijske politike.

- neposredno stvaranje poslova (eng. direct job creation) - može utjecati na stvaranje radnih mjesta koja inače ne bi postojala pod uobičajenim tržišnim uvjetima. Ponekad se stvara radno mjesto niže proizvodnosti nego što je ukupna plaća koju radnik prima. Postoji nada 
da će s vremenom porasti proizvodnost takvog radnika pa da će radno mjesto opstati i kada subvencije prestanu, ali za to nema nikakvih jamstava. Ukoliko je radno mjesto trajno vezano za nižu proizvodnost, ono se obično gasi kada poticaju prestanu.

- poticaji za nove tvrtke ili samozapošljavanje (eng. start-up incentives) - osim novaca za otvaranje vlastite tvrtke korisnicima donose određene obaveze i rizik od troškova koji se ponekad teško podmiruju. Ujedno, nezaposlene osobe često kod samozapošljavanja pokazuju pretjerani i/ili nedovoljno utemeljeni poduzetnički optimizam jer obično nisu dovoljno dobro proučile i realno procijenile vjerojatnost uspjeha u poslu. Ponekad im nedostaje poduzetnički duh, odlučnost, znanja, a gotovo uvijek poduzetničko iskustvo.

Važno pitanje u mjerama je i određivanje ciljane skupine, a baza EUROSTAT-a usmjerena je prije svega na intervencije $u$ kojima su uključene osobe s poteškoćama na tržištu rada. Ova specifikacija omogućava razlikovanje između politike tržišta rada i općenitije zapošljavanja s jedne strane te socijalne zaštite $\mathrm{i}$ fiskalne politike s druge strane, a koje mogu imati slične ciljeve u pogledu promicanja zapošljavanja, ali to čine na neselektivni način prema ukupnom stanovništvu.

\section{EVALUACIJE AKTIVNE POLITIKE TRŽIŠTA RADA U HRVATSKOJ}

U Hrvatskoj je bilo nekoliko evaluacija programa aktivne politike zapošljavanja. Dorenbos, Winden, Walsh, Svaljek i Milas (2002.) istraživali su značenje i učinke sudjelovanja u javnim radovima te su zaključili kako je sudjelovanje bitno u rješavanju ekonomskih teškoća sudionika, ali ne povećava njihovu zapošljivost. Babić (2003.) u jednoj od rijetkih evaluacija politike za- pošljavanja iz prvog desetljeća 21. stoljeća navodi kako su te mjere imale značajan učinak mrtvog tereta (korisnici bi se zaposlili i bez financijskih poticaja) te učinke zamjene i istiskivanja. Druga evaluacija odnosila se na procjenu učinaka programa javnih radova, za koji je ocijenjeno kako nije poboljšao zapošljivost ni nadnice sudionika nakon njegova završetka, ali ipak barem trenutačno poboljšava financijski položaj sudionika (Dorenbos i sur., 2002.). Glavna korist koja se očekuje od javnih radova nije toliko u izravnim ekonomskim dobicima, nego više u poticanju onih nezaposlenih za koje postoji mala potražnja na tržištu rada da se pridruže radnoj snazi. Kada se ispitivao način na koji javni radovi pomažu sudionicima, gotovo svi ispitanici $(96,9 \%)$ naveli su da im radovi pomažu barem na neki način. Istina, većina sudionika navela je kako im je program pomogao u poboljšanju financijskog stanja. Na nesreću, svi drugi učinci (pomoć u stvaranju socijalnih kontakata, pojačavanje povjerenja te dobivanje znanja i stručnosti) bili su mnogo manje naglašeni. Ovi nalazi pokazuju da se sudjelovanje u programima javnih radova u Hrvatskoj može (barem) djelomično smatrati kao privremeni način savladavanja financijskih problema. U taj program nisu uložena značajnija sredstva.

Oračić (2005.) je analizirao učinkovitost šest skupina mjera Programa poticanja zapošljavanja: »S faksa na posao«, »Iz učionice u radionicu «, »Učenjem do posla za sve nas«, »Iskustvom do profita «, »Šansa i za nas « $\mathrm{i} »$ Posao za branitelje «. Autor ističe kako je jedno od najvažnijih obilježja Programa bila njegova obuhvatnost u pogledu potencijalnih sudionika čije je zapošljavanje mogao subvencionirati. Premda su se pojedine mjere odnosile na određene ciljane skupine, zbroj ciljanih skupina obuhvaćao je veliku većinu nezaposlenih, te čak i osobe koje nisu bile registrirane kao nezaposlene. Procjena učinka poticanja zapošljavanja je pokušaj da se ustanovi koliko je poticanje 
zapošljavanja pridonijelo ukupnom zapošljavanju, odnosno koliko bi bilo manje ukupno zapošljavanje da nije bilo poticanja zapošljavanja. Kako je nemoguće promatrati pretpostavljeno stanje u kojem nije bilo poticanja zapošljavanja, a koje bi bilo identično stanju u kojem je ostvareno poticanje, Oračić učinak poticanja zapošljavanja pokušava procijeniti na temelju drugih raspoloživih podataka o stvarnom stanju, posebice pokazatelja o gospodarskim kretanjima. Na temelju multiregresijske analize, autor zaključuje kako je promjena poticanog zapošljavanja bila pozitivno povezana s promjenom ukupnog zapošljavanja, ali ta veza nije statistički značajna.

Može se ocijeniti da je u cjelini APZ u razdoblju 2002.-2005. s obzirom na broj zaposlenih bio učinkovit, ali nedovoljno usmjeren na teže zapošljive skupine, jer su gotovo sve osobe evidentirane pri HZZ-u mogle iskoristiti neku od poticajnih mjera. Ujedno je nepovoljno što mjere subvencioniranja nadnica čine pretežit dio ukupnih izdataka za mjere APZ-a, a nisu dovoljno naglašena pitanja povećanja razine stručnosti, znanja, sposobnosti zapošljivosti i prilagodljivosti te nezaposlenih i zaposlenih osoba. Zato je kao prioritet »Zajedničkog memoranduma o socijalnom uključivanju Republike Hrvatske« iz 2007. godine u području APZ-a određena potreba razvijanja »kulture evaluacije«, odnosno ispitivanja učinaka mjera APZ-a i izbjegavanja stihijskog pristupa (angažiranje značajnih sredstava i potom gašenja programa).

Aktivnosti sustavne evaluacije mjera APZ-a započele su razmjerno nedavno. Tako je ostvaren projekt »Evaluacija mjera aktivne politike tržišta rada u Hrvatskoj«. Riječ je o bilateralnom programu koji je započeo 2006. godine, a bazira se na suradnji austrijskog Ministarstva gospodarstva i rada s Ministarstvom gospodarstva, rada i poduzetništva (Uprava za rad i tržište rada) Republike Hrvatske i HZZ-a. Tijekom
2007. izrađena je studija »Evaluacija mjera aktivne politike tržišta rada u Hrvatskoj« te je u lipnju 2007. održan seminar pod nazivom »Praćenje i evaluacija mjera aktivne politike tržišta rada u Hrvatskoj« (Hrvatski zavod za zapošljavanje, 2008.). U projektu je korištena kombinacija kvantitativnih i kvalitativnih metoda sastavljenih od sljedećih glavnih evaluacijskih instrumenata: 1) prikupljanje postojećih podataka/ pregled dostupnih materijala, dokumenata, zakonodavstva, statistika itd., 2) analiza relevantne statistike i dokumenata, 3) terensko istraživanje u četiri odabrane županije i 4) posjete Hrvatskom zavodu za zapošljavanje glavnim dionicima na nacionalnoj razini. Pritom su se u obzir uzimali sljedeći aspekti: 1) vrsta mjera koje su se provodile na županijskoj razini za nezaposlene (paleta mjera) i to posebno za nezaposlene kojima prijeti socijalna isključenost, 2) definiranje i specifikacija ciljanih skupina i ciljeva pokrenutih aktivnosti, 3) posebni uvjeti unutar mjera neophodni za zadovoljavanje potrebe ciljanih skupina (na primjer: podrška sudionicima u vidu psihologa ili socijalnih radnika, organizacija obuka »kako naučiti« itd.), 4) opsežnost mjera u pogledu sudionika, karakteristike sudionika uključujući i raščlambu po dobi, spolu, obrazovanju, raspodjela ciljanih skupina, obuhvat razina sudjelovanja i stopa korisnika iz potencijalnog kruga korisnika), 5) neki aspekti vezani uz učinak mjera APZ-a i njihovu učinkovitost u vidu uspješnosti pronalaska posla sudionicima i vještina stečenih u mjerama, 6) čimbenici uspjeha i neuspjeha, 7) visina troškova, 8) usporedba različitih mjera u pogledu aspekta financijske koristi i 9) sustav upravljanja i kapaciteti za izradu, provedbu, praćenje i evaluaciju mjera APZ-a, uključenost i koordiniranost relevantnih dionika, odnosno, kapaciteti nacionalnih i regionalnih tijela HZZ-a za upravljanje i evaluaciju mjera APZ-a i kapaciteti zaposlenika HZZ-a za provedbu i praćenje mjera. Razmatrane su Mjera 1. Sufinanciranje 
zapošljavanja mladih osoba bez radnog iskustva, Mjera 2. Sufinanciranje zapošljavanja dugotrajno nezaposlenih osoba, Mjera 3. Sufinanciranje zapošljavanja ženskih osoba iznad 45 i muških osoba iznad 50 godina starosti, Mjera 4. Sufinanciranje zapošljavanja posebnih skupina nezaposlenih osoba, Mjera 5.1. Sufinanciranje obrazovanja za poznatog poslodavca (novozaposleni i zaposleni u cilju zadržavanja radnog mjesta) i 5.2. Sufinanciranje obrazovanja za nepoznatog poslodavca, Mjera 6. Javni radovi, Mjera O/N. Sufinanciranje obrazovanja za nepoznatog poslodavaca i Mjera O/P. Sufinanciranje obrazovanja za poznatog poslodavca - Romi koje su provedene u skladu sa sklopljenim ugovorima razdoblju od početka 2006. do 30. lipnja 2007. Ciljana skupina obuhvaćena ovom evaluacijom sastavljena je od: a) izravnih korisnika mjera (nezaposleni, polaznici obuke, zaposlene osobe, poslodavci) i b) relevantnih dionika/socijalnih partnera te predstavnika odjela za provedbu, odnosno, središnjice i područne razine HZZ-a. Razvijeno je 9 personaliziranih instrumenata istraživanja koji obuhvaćaju različite kategorije ciljanih skupina evaluacije u odnosu na rezultate/aspekte evaluacije koje je potrebno obuhvatiti (upitnici za poslodavce - korisnike mjera APZ-a, upitnici za zaposlenike - subvencionirano zapošljavanje, upitnici za zaposlenike - javni radovi, upitnici za polaznike obuke - obuka za poznatog poslodavca, upitnici za polaznike obuke - obuka za nepoznatog poslodavca, intervjui s poslodavcima - korisnicima mjera, intervjui sa zaposlenicima HZZ-a na razini regije/županije, fokus grupe dionika/socijalnih partnera na razini regije/ županije i fokus grupe dionika/socijalnih partnera na središnjoj razini (uključujući i središnjicu HZZ-a). Razvijeni su personalizirani instrumenti istraživanja kako bi se mogli »unakrsno provjeriti« glavni rezultati unutar istih instrumenata, ali i između različitih instrumenata. Istodobno, rezultati evaluacije korišteni su pri planiranju aktivnosti za jačanje kapaciteta HZZ-a. Cilj ostvarene aktivnosti jest prijenos znanja o evaluaciji mjera dionicima u i izvan $\mathrm{HZZ}$-a. Očekivani rezultati evaluacije su pregled i opsežna procjena relevantnosti, učinkovitosti, ekonomičnosti i rezultata mjera APZ-a (palete mjera) s opisom mjera koje udovoljavaju potrebama ciljanih skupina te opis i procjena sustava upravljanja i kapaciteta HZZ-a za izradu, provedbu, praćenje i evaluaciju mjera. Kao primjeri dobrih mjera, odnosno onih koje su dobro funkcionirale, navedene su gotovo sve mjere, pretežno zato što promoviraju bolje prilike za zapošljavanje nezaposlenih. Kao mjere koje nisu dobro funkcionirale ili su imale poteškoća u provedbi među ostalim navedene su: Mjere za osobe s invaliditetom (zbog niske razine subvencija za zapošljavanje i kratkog razdoblja trajanja subvencioniranog zapošljavanja te nedovoljno preciznog definiranja ciljne skupine), Mjera sufinanciranog zapošljavanja za posebne skupine nezaposlenih (zbog premalog poticaja za zapošljavanje i nedovoljne upućenosti poslodavaca), Mjere za sufinancirano zapošljavanje pripadnika romske nacionalne manjine (zbog nepouzdanosti i nepotpunosti HZZ-ove baza podataka i nedovoljne motiviranosti sudionika), Mjera sufinanciranja zapošljavanja dugotrajno nezaposlenih (jer prema mišljenju nekih poslodavaca, ova skupina nezaposlenih nije svoj posao obavljala na očekivanoj razini te je trebalo utrošiti dodatna sredstva kako bi im se pružila podrška). Nadalje, poteškoće su se javljale i stoga što Mjeru sufinanciranja obrazovanja evidentiranih nezaposlenih nije bilo moguće kombinirati s mjerama za poticanje zapošljavanja. Konačno, u slučaju Javnih radova, subvencija definirana mjerom nije se pokazala dostatnom da bi motivirala korisnike, a za mnoga tijela lokalnih vlasti obveza sufinanciranja od $50 \%$ bila je veliki problem, posebice u slabo razvijenim područjima. Zaključno, veći dio ispitanika općenito smatra kako 
su mjere APZ-a u načelu dobre i korisne jer istodobno promoviraju bolje prilike za zapošljavanje i razvoj kao i stjecanje radnog iskustva i novih vještina. Sudionici imaju više samopouzdanja vezanog uz svoj status zaposlene osobe, a mjere općenito doprinose smanjenju nezaposlenosti. Velik dio korisnika mjera (pojedinci i poslodavci) preporučili bi mjere prijateljima, kolegama, a velik dio poslodavaca nastavit cee koristiti mjere. U prijedlozima poboljšanja ističe se potreba unaprjeđenja dostupnosti i redovitosti informacija, nužnosti decentralizacije u planiranju i provedbi te usmjerenosti na korisnika. Također se ističe potreba češćeg kontaktiranja s poslodavcima te neophodnost duljeg razdoblja planiranja u kombinaciji s fleksibilnijim višegodišnjim planiranjem potrebnih financijskih sredstava.

Hrvatski zavod za zapošljavanje proveo je PHARE 2005. projekt »Aktivne mjere zapošljavanja za skupine kojima prijeti socijalna isključenost «, kojim se jačala sposobnost različitih aktera na hrvatskom tržištu rada u provođenju mjera APZ-a. Cilj projekta je izrada preporuka vezanih uz poboljšanje postojećeg sustava mjera i osmišljavanje novih mjera. Aktivnosti projekta sastojale su se od 4 komponente, od kojih se prva odnosi na evaluaciju učinkovitosti mjera aktivne politike tržišta rada u Hrvatskoj i sustava za njihovu primjenu i upravljanje. Za evaluacijsko istraživanje korišteni su kvalitativni (tzv. meki podaci) i činjenice (tzv. čvrsti podaci). Nakon pregleda i sveobuhvatne procjene relevantnosti, učinkovitosti i rezultata mjera APZ-a, navedena je potreba uvođenja nove filozofije u politiku hrvatskog tržišta rada. To podrazumijeva razvijanje odgovarajućih preventivnih i aktivnih mjere za ciljane skupine i to putem multidisciplinarnog pristupa kombiniranjem savjetovanja, osposobljavanja i programa zapošljavanja. Istaknuta je potreba fleksibilnosti i regionalne usmjerenosti pri planiranju provedbi APZ-a s time da se kod planiranja potreb- nih financijskih sredstava uzimaju u obzir regionalne različitosti. Nadalje, naglašena je važnost razvoja lokalnog partnerstva za zapošljavanje vezanog uz provedbu APZ-a, decentralizaciju i razvoj apsorpcijskih kapaciteta. Kao završni prijedlog podsjeća se kako su praćenje i evaluacija aktivnih politika bitan alat kojim se podiže razina odgovornosti politike, ali i poboljšava izvedba i kvaliteta provedbe mjera općenito, pa stoga postoji očita potreba za razvojem kapaciteta za praćenje i evaluaciju.

U okviru projekta »Žene na tržištu rada« provedena je sveobuhvatna analiza položaja žena na tržištu rada, kojom se željela dobiti jasna slika o sudjelovanju žena i njihovim mogućnostima na tržištu rada (Hazl, Meštrović, Crnković Pozaić, Taylor, 2011.). Također, definirane i analizirane su posebno osjetljive skupine žena na tržištu rada. Kroz projekt se željela ocijeniti učinkovitost već provedenih mjera aktivne politike tržišta rada namijenjenih ženama, s posebnim naglaskom na osjetljive skupine (npr. žene starije od 40 godina, neaktivne žene, dugotrajno nezaposlene žene, Romkinje i žene iz ruralnih područja). Nakon evaluacije spomenutih mjera, te na temelju najbolje prakse u Hrvatskoj i EU, pripremljen je prijedlog novog seta mjera aktivne politike zapošljavanja prilagođenih za ciljne skupine žena. U predlaganju poboljšanja navodi se važnost povećanja broja žena u programima osposobljavanja i prekvalifikacije, nužnost unaprjeđenja fleksibilnosti u načinu pružanja mjera osposobljavanja i prekvalifikacije kako bi one bile dostupne i ženama koje su slabije prometno povezane te promicanje posebnih programa i/ili projekata usmjerenih na povećanje sudjelovanja žena na tržištu rada, osobito u suradnji $\mathrm{s}$ jedinicama lokalne samouprave i drugim interesnim skupinama.

U prosincu 2011. godine završena je vanjska neovisna evaluacija aktivnih mjera politike zapošljavanja koje je provodio 
HZZ. Evaluaciju su proveli istraživači sa Sveučilišta u Zagrebu koristeći se kvazieksperimentalnom metodom, što je uobičajeni postupak istraživanja učinka mjera na zapošljivost sudionika. Autori su istraživali razlike u pogledu zapošljivosti između sudionika u mjerama nakon što je njihovo sudjelovanje završilo i sličnih osoba koje nisu sudjelovale u mjerama, pri čemu je zapošljivost mjerena statusom nezaposlenosti. Izabrani nesudionici bili su identični sudionicima prema osobnim obilježjima kao što su spol, godina rođenja, status prije nezaposlenosti, razina i smjer obrazovanja, geografsko područje prijave na evidenciju nezaposlenih te slični prema vremenu prijave i trajanju nezaposlenosti. Nesudionici su također izabrani i prema sličnosti u vjerojatnosti sudjelovanja u mjerama (engl. propensity score matching) koja je procijenjena na temelju spomenutih osobnih obilježja. Što se tiče obrazovanja nezaposlenih, ustanovljeno je kako ne postoje velike razlike između sudionika i nesudionika u pogledu nezaposlenosti nakon što je sudjelovanje prvih završilo. Kod sufinanciranja zapošljavanja mladih, udio nezaposlenih kod sudionika bio je $11 \%$, a kod nesudionika »dvojnika $24 \%$, tako da je razlika 13 postotnih bodova. Razlika je velika, ali postavlja se pitanje je li rezultat sudjelovanja, odnosno je li samo sudjelovanje povećalo zapošljivost sudionika jer dio razlike može odražavati selekciju od strane poslodavaca. Matković, Babić i Vuga (2012.) napominju da razlika vjerojatno djelomično odražava selekciju najzapošljivijih osoba od strane poslodavaca. Ako su stvarno izabrani najzapošljiviji, onda su sudionici i nesudionici zapravo bili različiti po zapošljivosti premda su bili slični po vanjskim mjerenim obilježjima ili vjerojatnosti sudjelovanja. Ako je postojala značajna razlika između sudionika i nesudionika u zapošljivosti prije sudjelovanja, onda rezultat ne pokazuje (u ovom slučaju vjerojatno precjenjuje) utjecaj sudjelovanja. Drugim riječima, sudionici su vjerojatno bili zapošljiviji od nesudionika i prije nego što je njihovo sudjelovanje započelo. Suprotan primjer su sudionici u javnim radovima kod kojih je vjerojatnost nezaposlenosti nakon završetka sudjelovanja bila veća nego kod sličnih nesudionika. Tako je, na primjer, vjerojatnost nezaposlenosti u listopadu 2011. godine za osobe koje su u 2009. godini sudjelovale u javnim radovima bila za 13 postotnih bodova veća nego kod nesudionika sličnih osobnih obilježja. Ta razlika bila je manja kada su se sudionici usporedili s nesudionicima slične vjerojatnosti sudjelovanja, ali imala je isti predznak. Autori napominju da to može odražavati selekciju, ali u suprotnom smjeru, jer se za sudionike javnih radova izabiru najteže zapošljive osobe. Sudionici su, dakle, bili vjerojatno manje zapošljivi od sličnih nesudionika i prije nego što je njihovo sudjelovanje započelo. U tom pogledu, javni radovi kao i programi obrazovanja nezaposlenih mogu imati pozitivnu i važnu ulogu jer pružaju novčanu pomoć i osiguravaju socijalni kontakt. Takav kratkoročni ili neposredni učinak mjera osobito je značajan tijekom razdoblja gospodarske krize, odnosno visoke nezaposlenosti. Izgleda, dakle, da je upotrijebljena kvazieksperimentalna metoda samo djelomično uklonila učinke selekcije sudionika, a dobiveni rezultati istraživanja ne mogu se smatrati posve pouzdanom osnovom za donošenje zaključaka u pogledu utjecaja mjera na zapošljivost sudionika. Međutim, kako je navedeno, bez obzira na njihov utjecaj na zapošljivost, neke od spomenutih mjera mogu se promatrati kao oblik uvjetovane pomoći nezaposlenima i kao oblik njihovog socijalnog uključivanja.

U dokumentu »Smjernice za razvoj i provedbu aktivne politike zapošljavanja u Republici Hrvatskoj za razdoblje od 2015.2017. godine« (Vlada Republike Hrvatske, 2014.) pozornost se posvećuje vjerojatnosti zaposlenosti nakon izlaska iz mjera aktivne politike zapošljavanja koja se uvelike razlikuje ovisno o tipu mjere i obilježjima 
njezinih sudionika. Vjerojatnost zaposlenosti je najviša za osobe koje su i pred sudjelovanje u mjeri bile zaposlene: potporama za očuvanje radnih mjesta i potporama za usavršavanje, gdje je 94,0\%, odnosno 95,7\% sudionika i ostalo zaposleno. Slijede mjere potpore samozapošljavanja $(79,2 \%)$ i zapošljavanja $(74,4 \%)$, gdje je između tri četvrtine i četiri petine sudionika zaposleno pola godine nakon izlaska iz intervencije. Gotovo polovica $(47,4 \%)$ sudionika stručnog osposobljavanja bez zasnivanja radnog odnosa bila je zaposlena u danom roku, pri čemu je vjerojatnost zapošljavanja bila veća za visokoobrazovane $(50,4 \%)$ nego za osobe sa srednjim obrazovanjem $(32,9 \%)$. U razdoblju od šest mjeseci nakon izlaska iz mjere zaposleno je bilo nešto manje od trećine $(32,9 \%)$ izabranih sudionika programa za obrazovanje nezaposlenih, a vjerojatnost zaposlenosti nakon izlaska iz mjere najniža za sudionike javnih radova $(9,7 \%)$, koji su u mjeru i selektirani s obzirom na kriterij dugotrajne nezaposlenosti i vrlo niske zapošljivosti.

Posljednju evaluaciju proveo je tim Ipsos Pulsa (Hrvatski zavod za zapošljavanje i Ipsos Puls, 2016.). Ova evaluacija obuhvaća mjere aktivne politike zapošljavanja koje su se provodile u razdoblju između 2010. i 2013. godine kako bi se utvrdila njihova uspješnost pri čemu se mjerio učinak na mogućnost zapošljavanja sudionika u mjerama u usporedbi s članovima kontrolne grupe koji u njima nisu sudjelovali. Službeni podaci nadležnih tijela upotpunjeni su informacijama dobivenima kroz upitnike, intervjue te fokus grupe, kako bi se procijenila očekivanja korisnika mjera - poslodavca i nezaposlenih osoba, njihovo zadovoljstvo i samo iskustvo sudjelovanja u pojedinim mjerama. Na taj način stvorena je čvrsta podloga za daljnji razvoj i unaprjeđenje APZ-a. To je bila sveobuhvatna evaluacija mjera APZ-a u Hrvatskoj, kako bi se stvorila temeljita osnovica za reviziju postojećeg sustava mjera i općeg pristupa vođenju aktivne politike zapošljavanja. Projektnim zadatkom predviđeno je provođenje triju osnovnih komponenti istraživanja: a) Evaluacija učinkovitosti mjera aktivne politike tržišta rada tehnikom uparivanja prema srodnosti (eng. propensity score matching - PSM), b) Kvalitativno istraživanje metodom fokus grupa i dubinskih intervjua i c) Kvantitativno istraživanje metodom ankete (online i osobne ankete).

U užem smislu evaluacije mjera APZ-a u prvom redu se shvaćaju kao evaluacija učinkovitosti tih mjera na mikroekonomskoj razini u smislu utjecaja intervencije na rizik od kasnije nezaposlenosti, odnosno zaposlenosti, ali i visine prihoda koju ostvaruje osoba koja je sudjelovala u mjerama. Ovakva evaluacija se u jednostavnijem slučaju bazira na jednostavnom praćenju statusa nezaposlenosti, odnosno zaposlenosti za korisnike mjere nakon proteka određenog vremena od izlaska korisnika iz mjere. Takav pristup, iako praktičan i jednostavan, ima znatne metodološke manjkavosti: a) selektivnost procesa izbora korisnika određene mjere s obzirom na obilježja korisnika i b) teško je ili nemoguće učinke izolirati od utjecaja ostalih procesa važnih za tržište rada (na primjer, opći porast mogućnosti zapošljavanja). Međutim, evaluacija učinkovitosti mjera u užem smislu nije dostatna za cjelovitu evaluaciju mjera APZ-a te temeljem nje eventualnu njihovu reviziju. Razlog je prije svega što nemaju sve mjere iste ciljeve: neke mjere APZ-a ne moraju za cilj imati samo dugoročno rješavanje problema nezaposlenosti za pojedine skupine, nego mogu imati i određene kratkoročne ili meke ciljeve (npr. kratkoročni izlazak iz nezaposlenosti za određene skupine nezaposlenih, aktivacija, stjecanje određenih iskustava i vještina itd.). Drugo, evaluacija učinaka ne daje odgovor zbog čega određena mjera nije dovoljno učinkovita (apsolutno i relativno), odnosno što smanjuje njezinu učinkovitost. Potrebno je razumjeti sve aspekte implementacije mjere, kako bi 
se mogli utvrditi mogući uzroci »neuspješnosti« ili pak »uspješnosti« neke mjere ili skupina mjera. Stoga su nužni dodatni izvori informacija i drugi tipovi spoznaja. Treće, pitanje procesa i procedura implementacije mjera te iskustva korisnika i drugih dionika je važno pitanje čak i u slučajevima kada su mjere ocijenjene vrlo učinkovitima. Prethodna iskustva korisnika, na primjer, poslodavaca, mogu značajno utjecati na njihovu spremnost da sudjeluju u budućim mjerama. U konačnici, evaluacija treba pomoći poboljšanju procedura i procesa implementacije mjera čak i ako takva poboljšanja neće imati nikakav učinak na učinkovitost konkretne mjere ili budućih srodnih mjera, jer pojednostavljenje procedure može donijeti snižavanje operativnih troškova implementacije mjera ili poboljšati radne uvjete zaposlenika agencija koja implementira mjere. Stoga je u ovom projektu provedeno i sveobuhvatno kvalitativno te kvantitativno istraživanje.

Pohvalno je što Vlada RH (2020.) navodi kako su socijalni partneri istaknuli potrebu provođenja hitne vanjske evaluacije mjera aktivne politike zapošljavanja. Stoga je HZZ u fazi pripreme natječajne dokumentacije za vanjsku evaluaciju koja će obuhvatiti razdoblje 2014.-2019. godine i koja bi trebala biti dovršena do kraja 2021. godine.

\section{ZAKLJUČAK}

Iako je Hrvatska mnogo učinila na povećanju obuhvata mjera APZ-a i njihovoj boljoj usmjerenosti na osobe koje su u najlošijem položaju na tržištu rada, još uvijek postoji potreba i prostor za daljnja unaprjeđenja. Može se ocijeniti da Hrvatska uglavnom ide u pravcu politika zapošljavanja što se provode u Europi, koje obilježava jači naglasak na aktivne mjere u odnosu na one pasivne. Iako su u Hrvatskoj povećana izdvajanja za APZ, problemi su bili vezani uz njihovo kratko trajanje i relativno nisku konzistentnost. Ujedno, mjere su ranije u najvećoj bile usmjerene na subvencioniranje zapošljavanja koje nedovoljno unaprjeđuje znanja, stručnosti i sposobnosti nezaposlenih te stoga u cjelini ne pomaže poboljšanju zapošljivosti polaznika. Mjere poput stručnog osposobljavanja za rad bez zasnivanja radnog odnosa s ciljem stjecanja radnog iskustva i poboljšanja zapošljivosti počele su se intenzivnije usmjeravati na osobe s nižom razinom zapošljivosti i dugotrajno nezaposlene, što je značajan pozitivan kvalitativni korak u njihovom oblikovanju i provedbi. Prema viđenju različitih dionika, mjere APZ-a u cjelini su dovoljno dostupne i svi potencijalni korisnici mjera dovoljno dobro informirani o njima. Ispitanici navode kako su mjere pozitivne i za poslodavce $\mathrm{i}$ za nezaposlene osobe prijavljene HZZ-u te definitivno svi imaju koristi od toga. Mjere su dobro usmjerene prema mladima i prema zapošljavanju osoba iznad 50 godina, dok su javni radovi namijenjeni ponajviše dugotrajno nezaposlenim osobama. Poslodavci su zadovoljni jer u cijeloj lepezi mjera mogu naći neke koje mogu koristiti. Neto efekt između zaposlenosti eksperimentalne i kontrolne skupine kod potpora i slijedom toga učinkovitost su najniži kod javnih radova, a prilično je nepovoljno i kod potpora za obrazovanje. Najbolji su učinci kod potpora za samozapošljavanje i kod onih za starije i za dugotrajno nezaposlene osobe. Uz sva ograničenja vezana uz nepostojanje longitudinalnih podataka, nemogućnosti usporedbe s drugim zemljama jer su mjere sadržajno različite i namijenjene drugim skupinama korisnika te neraspolaganje podataka za ranija razdoblja u Hrvatskoj, može se procijeniti kako je učinkovitost mjera aktivne politike zapošljavanja u razdoblju 2010.-2013. u cjelini bila na zavidnoj razini.

Kod općeg oblikovanja i provedbe mjera APZ-a najznačajniji prijedlozi za sve mjere su da treba pojačati transparentnost i svrhovitost mjera te njihovo što bolje ciljanje 
i prilagođavanje pojedinoj skupini nezaposlenih osoba. Istodobno, treba ostvariti njihovo što bolje usklađivanje sa zahtjevima i promjenama na tržištu rada, osigurati financijsku održivost mjera kako se ne bi dogodilo njihovo prekidanje zbog nedostatka sredstava. Nužno je objediniti mjere i ukinuti one za koje je vrlo slabo zanimanje te preimenovati neke mjere kako bi bilo jasnije o čemu se radi. Nadalje, treba proučiti opravdanost, prednosti i nedostatke veće fleksibilnosti pri određivanju trajanja pojedinih mjera (npr. javnih radova) i/ili iznosa odobrenih sredstava. Važno je ne mijenjati stalno sadržaje i kriterije mjera (na primjer, nadopunu dokumentacije) tijekom ciklusa provođenja mjera, razmotriti mogućnost pojednostavljenja cjelokupnog postupka traženja dokumentacije, posebice razvijanjem sustava dobivanja elektronskih potvrda od nadležnih tijela, kao što je porezna uprava. Konačno, potrebno je pojasniti uvjete sudjelovanja i pripremiti lako razumljive upute o njihovom korištenju koje neće kasniti i poboljšati dostupnost i kvalitetu informacija prema nezaposlenima i prema poslodavcima. Najkraće, mjere APZ-a treba prilagođavati promijenjenim uvjetima, ali pritom treba težiti njihovoj stabilnosti i trajnosti kako se u nedoumicu ne bi doveli mogući korisnici i djelatnici HZZ-a.

\section{LITERATURA}

Babić, Z. (2003). Uloga aktivne politike na tržište rada u Hrvatskoj. Financijska teorija i praksa, 27(4), 547-566. https://hrcak.srce.hr/5771

Babić, Z. (2012). Aktivna politika tržišta rada: europski kontekst i hrvatska praksa. Socijalna ekologija, 21(1), 31-52. https://hrcak.srce.hr/79120

Bonoli, G. (2010). The political economy of active labor-market policy. Politics \& Society, 38(4), 435457. https://doi.org/10.1177/0032329210381235

Directorate General for Employment, Social Affairs \& Inclusion. (2011). Evaluation of labour market policies and programmes: Methodology and practice. Brussels: Directorate General for Employment, Social Affairs \& Inclusion. Ava- ilable at http://ec.europa.eu/social/main.jsp?catId=1070\&langId=en\&newsId=1953\&furtherNews=yes

Directorate General for Employment, Social Affairs \& Inclusion. (2012). Evaluation of labour market policies and programmes: The use of data-driven analysis. Brussels: Directorate General for Employment, Social Affairs \& Inclusion. Available at http://ec.europa.eu/social/main. jsp?catId=1070\&langId=en\&newsId=1946\&furtherNews=yes

Diamond, P., \& Lodge, G. (2013). European welfare states after the crisis: Changing public attitudes, policy network paper. London: Policy Network.

Dorenbos, R., van Winden, P., Walsh, K., Svaljek, S., \& Milas, G. (2002). Evaluation of program of public works in Croatia - Final report. Rotterdam: NEI Labour and Education \& T.E.R.N.

Eurostat. (2013). Labour market policy statistics, Methodology 2013. Luxembourg: Eurostat. Available at http://ec.europa.eu/eurostat/documents/3859598/5935673/KS-GQ13-002-EN.PDF/bc4d9da7-b375-4eb3-97c7$766 \mathrm{ebf} 7 \mathrm{~b} 4 \mathrm{aa} 0$ ? version $=1.0$

Grosh, M., del Ninno, C., Tesliuc, E., \& Ouerghi, A. (2008). For protection and promotion: The design and implementation of effective safety nets. Washington, D.C.: The World Bank.

Farnsworth, K., \& Irving,Z. (2010). Varieties of crisis within variable capitalisms: Contemplating the implications of economic crisis for social policy. Paper presented at the Social Policy Association Annual Conference University of Lincoln, 5-7 July 2010.

Hazl, V., Meštrović, B., Crnković Pozaić, S., \& Taylor, A. (2011). Žene na tržištu rada. Europe Aid/128290/D/SER/HR (E1896). Zagreb: Hrvatski zavod za zapošljavanje.

Hrvatski zavod za zapošljavanje. (2008). Evaluacija mjera aktivne politike tržišta rada koje provodi Hrvatski zavod za zapošljavanje Phare 2005 program Europske unije za Hrvatsku »Evaluacija, izrada preporuka, jačanje kapaciteta $i$ upravljanje darovnicom na području mjera poticanja zapošljavanja u $R H$ «. Zagreb: Hrvatski zavod za zapošljavanje.

Hrvatski zavod za zapošljavanje. (2008). Preporuke za poboljšanje sadašnjih mjera APTR-a, izradu novih mjera i poboljšanje kapaciteta HZZ-a za programiranje, provedbu, praćenje $i$ evaluaciju mjera APTR-a. Zagreb: Hrvatski zavod za zapošljavanje.

Hrvatski zavod za zapošljavanje \& Ipsos Puls. (2016). Vanjska evaluacija mjera aktivne politike tržišta 
rada 2010.-2013. Sumarno evaluacijsko izvješće. Zagreb: Hrvatski zavod za zapošljavanje.

Matković, T., Babić, Z., \& Vuga, A, (2012). Evaluacija mjera aktivne politike zapošljavanja 2009. i 2010. godine u Republici Hrvatskoj. Revija za socijalnu politiku, 19(3), 303-336. https://doi. org/10.3935/rsp.v19i3.1100

Matković, T. (2008). Politika zapošljavanja i nezaposlenosti. U V. Puljiz, G. Bežovan, T. Matković, Z. Šućur \& S. Zrinščak (ur.), Socijalna politika Hrvatske. Zagreb: Pravni Fakultet Sveučilišta u Zagrebu.

Mrnjavac, Ž. (2013). Aktivna politika tržišta rada: čačkalicom protiv zmaja. 7. zagrebački ekonomski forum. Zagreb: Friedrich-Ebert-Stiftung.

Münich, D., Svejnar, J., \& Terrell, K. (1999). Worker-firm matching and unemployment in the transition to a market economy: (Why) are the Czechs more successful than others?. CERGE-EI Working Papers, No. 141. Available at http:// www.cerge-ei.cz/pdf/wp/Wp141.pdf

Nekić, M. (2014). Mjere aktivne politike zapošljavanja u Hrvatskoj. Radno pravo, 9(2), 65-70.
Oračić, D. (2005). Evaluacija Programa poticanja zapošljavanja. Analitički bilten, (3), 20-32, Dostupno na http://www.hzz.hr/UserDocsImages/ Bilten2005_3.pdf

Starke, P., Kaasch, A., \& van Hooren, F. (2011). Explaining the variety of social policy responses to economic crisis: How parties and welfare state structures interact. TranState working papers, No. 154. Available at http://hdl.handle. net/10419/50561

Vlada Republike Hrvatske. (2014). Smjernice za razvoj i provedbu aktivne politike zapošljavanja u Republici Hrvatskoj za razdoblje od 2015.-2017. godine. Zagreb: Vlada Republike Hrvatske.

Vlada Republike Hrvatske. (2020). Nacionalni program reformi 2020. Zagreb: Vlada Republike Hrvatske. Dostupno na https://vlada.gov.hr/UserDocsImages/2016/Sjednice/2020/Travanj/227\%20sjednica\%20VRH/Novi\%20direktorij/227\%20-\%201.pdf
Priredio: Predrag Bejaković
Institut za javne financije 